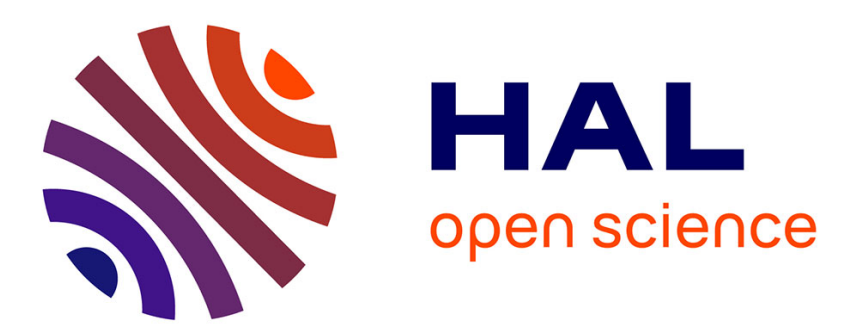

\title{
An observational study of benzodiazepine prescription during inpatient alcohol detoxification for patients with versus without chronic pretreatment with high dosage baclofen
}

Nicolas Simon

\section{To cite this version:}

Nicolas Simon. An observational study of benzodiazepine prescription during inpatient alcohol detoxification for patients with versus without chronic pretreatment with high dosage baclofen. Fundamental \& Clinical Pharmacology, 2018, 32 (2), pp.198-199. 10.1111/fcp.12354 . inserm-01968955

\section{HAL Id: inserm-01968955 https://www.hal.inserm.fr/inserm-01968955}

Submitted on 3 Jan 2019

HAL is a multi-disciplinary open access archive for the deposit and dissemination of scientific research documents, whether they are published or not. The documents may come from teaching and research institutions in France or abroad, or from public or private research centers.
L'archive ouverte pluridisciplinaire HAL, est destinée au dépôt et à la diffusion de documents scientifiques de niveau recherche, publiés ou non, émanant des établissements d'enseignement et de recherche français ou étrangers, des laboratoires publics ou privés. 


\title{
EDITORIAL \\ An observational study of benzodiazepine prescription during inpatient alcohol detoxification for patients with versus without chronic pretreatment with high dosage baclofen
}

\author{
Nicolas Simon ${ }^{\mathrm{a}, \mathrm{b}}$ \\ a APHM, Hôpital Sainte Marguerite, Service de Pharmacologie Clinique, CAP-TV, 13274, Marseille, France \\ ${ }^{\mathrm{b}}$ UMR 912 INSERM, IRD, SESSTIM, Aix Marseille University, 13005 Marseille, France
}

\begin{abstract}
This editorial refers to the article 'An observational study of benzodiazepine prescription during inpatient alcohol detoxification for patients with versus without chronic pretreatment with high dosage baclofen' by Laura Martinez et al. published in the April 2018 issue of Fundamental and Clinical Pharmacology.
\end{abstract}

\begin{abstract}
Alcohol reduction is currently suggested to most patients with alcohol use disorder (AUD); those who do not require acute detoxification. The treatment strategy to help patients decrease their alcohol consumption varies from country to country. In France, a wide use of baclofen is observed in this indication since the publications of Addolorato's article [1] and Ameisen's book [2]. The benefit of this approach is still a matter of debate among addiction specialists. A drug approval is under evaluation at the French national drug agency (ANSM). In the meantime, there are still plenty of patients, among whom some are improved and can be considered as positive responders, but others are not. An open-study - evaluating the relationship between baclofen dose, exposure and craving during the first 3 months of treatment - showed a significant decrease in craving in 38\% of patients [3]. Other studies with a randomized and double-blind design described conflicting results [4]. Meanwhile, high doses of baclofen aiming to help patients decrease their consumption are commonly and fairly successfully used and cannot be ignored.

For some patients, the story is somewhat more complicated and despite intensive baclofen use, alcohol detoxification could be required. Such clinical situations will probably arise more and more frequently, and they deserve special attention. Considering that baclofen and benzodiazepine share some side effects, a synergy cannot be ruled out. Furthermore, due to the baclofen mechanism of action, it could be hypothesized that high dosage will lead to a loss of receptor specificity and a stimulation of GABA-A receptor. In an observational
\end{abstract}

clinical study, Martinez et al. [5] addressed this question and interestingly, they did not observe any significant difference between the doses of benzodiazepine required for their patients during detoxification. Despite certain limitations, such as the open and retrospective design as well as the small number of patients included, their results are of interest and worth discussing. However, there is a remaining question about the rational of maintaining baclofen if the patient does not respond. This question raises another one: if alcohol detoxification is required in a patient with insufficient response to baclofen, what should be stopped first, baclofen or alcohol? We also need to define 'failure of baclofen' by deciding to what extent an escalation should be explored? Indeed, in the world of pharmacology, there is no example of a drug active on $100 \%$ of patients. It must be admitted that some patients may not respond appropriately or exhibit adverse effects leading to baclofen reduction or withdrawal.

The article by Martinez et al. [5] provides some information on the management of patients with AUD under baclofen treatment and requiring alcohol detoxification, but a lot remains to be known.

\section{REFERENCES}

1 Addolorato G., Caputo F., Capristo E. et al. Baclofen efficacy in reducing alcohol craving and intake: a preliminary doubleblind randomized controlled study. Alcohol Alcohol. (2002) 37 504-508.

2 Ameisen O.. The end of my addiction, 1st edn, Farrar Straus Giroux, New York, NY, 2008. 
3 Imbert B., Alvarez J.C., Simon N. Anticraving effect of baclofen in alcohol-dependent patients. Alcohol. Clin. Exp. Res. (2015) 39 1602-1608.

4 Palpacuer C., Duprez R., Huneau A. et al. Pharmacologically controlled drinking in the treatment of alcohol dependence or alcohol use disorders: a systematic review with direct and network meta-analyses on nalmefene, naltrexone, acamprosate, baclofen and topiramate. Addiction (2018) 113 220-237.
5 Martinez L., Vorspan F., Decleves X. et al. An observational study of benzodiazepine prescription during inpatient alcohol detoxification for patients with versus without chronic pretreatment with high dosage baclofen. Fundam. Clin. Pharmacol. (2018) 32 200-205. https://doi.org/10.1111/fcp. 12339. 